\title{
GNATHOTRICHUS MATERIARIUS (FITCH, 1858) (COLEOPTERA: CURCULIONIDAE, SCOLYTINAE) - NEW SPECIES OF BEETLE IN THE POLISH FAUNA
}

\author{
Radosław Witkowski ${ }^{1}$, Jarosław Góral ${ }^{2}$, Katarzyna Nowik², Grzegorz Rogowski², \\ Katarzyna Skałecka², Andrzej Mazur ${ }^{1 \otimes}$ \\ ${ }^{1}$ Department of Forest Entomology, Poznań University of Life Sciences \\ Wojska Polskiego 71 C, 60-625 Poznań, Poland \\ ${ }^{2}$ Forest Protection Service, The State Forests National Forest Holding \\ Grunwaldzka 94, 50-357 Wrocław, Poland
}

\begin{abstract}
Gnathotrichus materiarius (Fitch, 1858) is an alien species in the European fauna. In Poland, this species has not been recorded thus far, although it was assumed that it may be present. This paper presents the first site of $G$. materiarius in Poland. A single individual of the beetle was captured during monitoring activities of the Double-spined bark beetle - Ips duplicatus (Sahlb.) in the pheromone traps with ID Ecolure pheromone in the Kamienna Góra Forest District, Krzeszów forest circle. Selected aspects of this species' ecology in the European conditions were discussed: capturing of Double-spined bark beetles in pheromone traps intended for various coniferous tree bark beetles, species' low count, possibility of the presence of two generations in one season and vertical distribution at various heights above sea level.
\end{abstract}

Key words: Gnathotrichus materiarius, new species for Poland, pheromone traps

\section{INTRODUCTION}

Gnathotrichus materiarius (Fitch, 1858) is an alien species in Europe which was brought from the Nearctic zone (Wood, 1982). The natural zone of its presence includes Canada, USA and the Antilles. Currently it is present also in Austria (Schedl, 1980), Belgium (Moucheron and Warzee, 2006), Czech Republic (Knížek, 2009), Finland (Valkama et al., 1997), France (Balachowsky, 1949), Spain (López et al., 2007), Holland (Wood and Bright, 1992), Germany (Schedl, 1966), Switzerland (Hirschheydt, 1992), Sweden (Gillerfors, 1988), Italy (Faccoli, 1998) and Slovenia (Jurc et al., 2012). In Europe, it was first identified in France in 1933 (Balachowsky, 1949).
G. materiarius is a xylomycetophagous species (ambrosia mycetobiont) feeding on coniferous species, mainly Pinus sp., Picea sp., Larix sp., Tsuga sp., Thuja sp., Pseudostsuga sp. (Blackman, 1931; Balachowsky, 1949; Doom, 1967; Hirschheydt, 1992). The arrangement of tunnels is very similar to feeding sites of ambrosia beetles, whereby the diameter of tunnels is ca. $1 \mathrm{~mm}$ smaller than in ambrosia beetles (Doom, 1967). The larvae of G. materiarius feed on mycelium of Endomycopsis fasciculata L. R. Batra 1963. In Germany, the beetles hatch between the end of April and mid-June (Gauss, 1971; Postner, 1974). 


\section{MATERIAL AND METHODS}

The species was identified during monitoring activities of the Double-spined bark beetle - Ips duplicatus (Sahlb., 1836) within the territory of the Regional Directorate of State Forests in Wrocław. The monitoring activities involved the application of barrier traps - Theysohn model with "ID Ecolure" pheromone. The traps were set up in forests of Norway spruce Picea abies (L.) H. Karst.) from the last week of April until the first week of September. The insects captured were collected every 10 days into plastic containers by state forest employees, described and preserved in the ethyl alcohol solution. The taxa of the collected material were identified at the Department of Forest Entomology of the Poznan University of Life Sciences.

\section{RESULTS AND DISCUSSION}

Among the collected beetles, one specimen of Gnathotrichus materiarius was found which was captured on the following site: Central Sudetes, Kamienna Góra Forest District, Krzeszów forest circle, division 120c (UTM: WS72) 1 ex., leg. K. Krajcarz et E. Gacek 5.06.2015, det. et coll. R. Witkowski (Fig. 1).

In the division $120 \mathrm{c}$, spruce forest aged 111 years with a canopy closure of 0.4 , in a habitat of mountainous mixed fresh forest (LMGśw). The site is located at the level of $500 \mathrm{~m}$ ASL.

It is the first case of this species' presence in Poland based on an individual captured within the territory of Poland. It is the only representative of subtrive Corthylina Le Conte, 1876 and the second individual from the tribe Corthylini Le Conte, 1876 found in Poland.

This species is an alien species in Europe. The details of how it spread in the Western Europe is presented in the paper by Hirschheydt (1992). However, looking into how it spread on the European continent (since 1933 in France, 1964 Germany, ca. 1984 and 1992 Switzerlad, 1988-1990 Scandinavia (Balachowsky, 1949; Glanditsch, 1969; Hirschheydt, 1992; Gillerfors, 1988; Schroeder, 1990; Engesser et al., 2007) shows no characteristics of an invasive species. Single individuals of $G$. materiarius were captured at many sites.

The possibility of its presence and potential importance in the Polish forest industry is highlighted by Grodzki and Mokrzycki (2014); Mokrzycki (2015), underlining the fact that this species has not been identified in Poland until now.

The information provided in the catalog of Palaearctic beetles (Knížek, 2011) regarding the presence of $G$. materiarius in Poland is considered erroneous which was already verified by Mokrzycki et al. (2011).

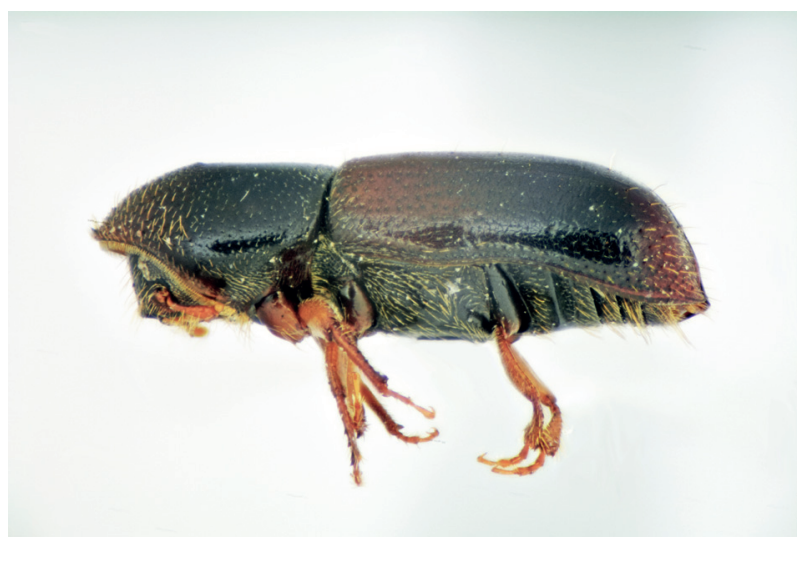

Fig. 1. Adult of Gnathotrichus materiarius (Fitch, 1858), photo R. Witkowski

Rys. 1. Chrząszcz Gnathotrichus materiarius (Fitch, 1858), fot. R. Witkowski

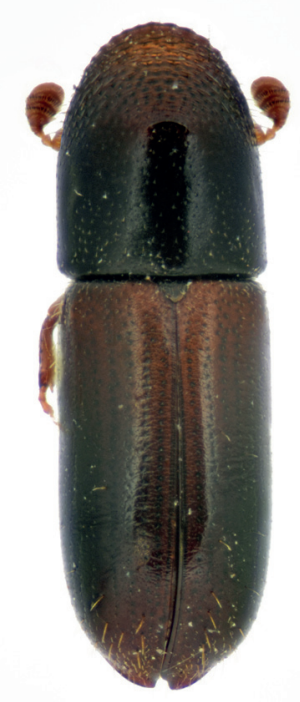


The information provided by Knížek (2011) was not confirmed in any paper and there were no details of the site, date and persons who collected it as well as there were no actual specimens. Also the catalogs regarding invasive species do not mention its presence in Poland [www.europe-aliens.org; www.iop.krakow.pl].

It follows from the observations of $G$. materiarius in the European conditions that it accompanies the species from the genus Ips spp. and it is often captured in pheromone traps. In the north-western Germany (area of Lingen, Emsland) G. materiarius was being captured in pheromone traps intended for Large larch bark beetle - Ips cembrae (Heer). In the season of 1983 (between 3.06 and 6.09) 100 individuals were captured, whereas in the season of 1984 (between 3.05 and 5.07) - 39 individuals were captured. In the first year, the captures of G. materiarius had two peaks: on 22.0668 individuals were captured and on $4.08-20$ individuals. In the following year, despite the fact that the traps were installed from the beginning of May to the beginning of October, G. materiarius was only captured until 5th of July, with peak number captured on 2 June (Schneider, 1985). This data may indicate that G. materiarius in the west Germany may develop two generations a year.

It follows from the studies in Canada that the beetles tend to be attracted in large numbers to traps with ethanol (Sweeney et al., 2007). Besides, a positive reaction of male G. materiarius to sulcatol $\left(\mathrm{C}_{8} \mathrm{H}_{16} \mathrm{O}\right)$ was observed (Flechtmann and Berisford, 2003). In the area of Cologne, also the flights of beetles of alien species (Xylosandrus germanus and Gnathotrichus materiarius) to felled and barked spruce trees were observed (Zach et al., 2001). The first captured beetles of G. materiarius in the Czech Republic (in 2005 and 2008) are from pheromone traps set up for Ips duplicatus (Knižek, 2009). In Switzerland, Germany and Finland, the beetles were found also in the pheromone traps for Striped ambrosia beetle - Trypodenron linetaum (O1.) and Six-toothed bark beetle - Ips sexdentatus (Börn.). In turn, the first individuals of G. materiarius in Italy and Finland were captured in traps set up for European spruce bark beetle containing Ipsolure ${ }^{\circledR}$ pheromone (Faccoli, 1998; Valkama et al., 1998). The last authors discuss also the capability of acclimatization of this species in Scandinavia, taking into account its vertical arrangement compared for sites from France, Benelux, Germany and Switzerland (Hirschheydt, 1992) as well as Bavaria (Blaschke and Bussler, 2012). The list shows that G. materiarius is present at heights of 200 to $1000 \mathrm{~m}$ ASL.

What are the routes and possibilities of spreading of this species in Central Europe?

It has been more than 80 years since G. materiarius was first identified in France. During this time, the species spread in northern part of Central Europe, entering Scandinavia as well. The site in Poland seems to be one of the most easternly, because the species was not recorded in eastern Germany (Köhler and Klausnitzer, 1998; Köhler, 2000). It is of particular importance that the sites in the Czech Republic located close to the German border (Horšovský Týn) (Knižek, 2009) are of the same character as the new site near Krzeszów - they are situated at the level of ca. $500 \mathrm{~m} \mathrm{ASL}$ and the beetles were captured by traps with the pheromone attracting Ips duplicatus. It seems more probable that G. materiarius could reach Poland from the south. It is also because south of Poland, numerous cases of spruce forest stand degeneration, as well as periodical fluctuations in spruce bark beetles are observed. Among them, of increasing importance is the the Double-spined bark beetle whose local outbreaks were recorded in the Czech Republic (mainly in Moravia and Silesia) since 1990 (Knižek and Zahradník, 1996; Knižek and Liška, 2012) and in Poland (Grodzki, 1997; 2003). These situations are accompanied by migration of the Double-spined bark beetle to increasingly higher located areas (Holuša et al., 2013) and different manner of how trees are infected (Grodzki, 2012).

\section{CONCLUSIONS}

Identification of Gnathotrichus materiarius in Poland confirms the presence of this species in forest habitats. The site is located near the southern state border and it is probable that this species may spread towards the north.

Most cases of finding of this species in the European fauna is based on single individuals captured in pheromone traps. Furthermore, the rate of spreading into new territories is slow to the extent that this species may hardly be considered invasive. The deteriorating health condition of spruce forest stands in 
Central Europe results in increasing populations of spruce bark beetles which may suggest occurrence of conditions which are conducive to spreading of $G$. $m a-$ teriarius in Poland and Europe.

\section{ACKNOWLEDGEMENTS}

The authors would like to thank the employees of the Kamienna Góra forest district for their keen help in conducting the monitoring activities.

\section{REFERENCES}

Balachowsky, A. (1949). Coléopteres Scolytides. - Faune de France 50, 1-320.

Blackman, M. W. (1931). A revisional study of the genus Gnathotrichus Eichhoff in North America. J. Wash. Acad. Sci., 21, 264-276.

Blaschke, M., Bussler, H. (2012). Borkenkäfer und baumschädigende Holzpilze in einem Höhengradienten des Bayerischen Waldes. Forstschutz. Aktuell. 54, 10-15.

Doom, D. (1967). Notes on Gnathotrichus materiarius (Col. Scolytidae), a timber beetle new to the Netherlands. Entomol. Ber. (Amsterdam) 27, 143-148.

Engesser, R., Forster, B., Meier, F., Wermelinger, B., Rogling, D. (2007). Introduced pests and diseases in Switzerland. In: H. Evans, T. Oszako (Eds.), Alien invasive species and international trade. Warszawa: IBL.

Faccoli, M. (1998). The North American Gnathotricus materiarius (Fitch) (Coleoptera Scolytidae): An ambrosia beetle new to Italy. Redia, 81, 151-154.

Flechtmann, C. A. H., Berisford, C. W. (2003). Identification of sulcatol, a potential pheromone of the ambrosia beetle Gnathotrichus materiarius (Col., Scolytidae). J. Appl. Entomol., 127(4), 189-194.

Gauss, R. (1971). Eingeschleppter Nutzholzborkenkäferbedroht unser Nadelholz. Allg. Forstztschr., 26, 469-471.

Gillerfors, G. (1988). Skalbaggar införda till Sverige med importerad massaved. Entomol. Tidskr., 9, 42-45.

Glanditsch, S. (1969). Neue Beobachtungen über den eingeschleppten Scolytiden Gnathotrichus materiarius Fitch. Mitt. Entomol. Ver. Stuttgart, 4, 76-78.

Grodzki, W. (1997). Możliwości kontroli liczebności populacji kornika zrosłozębnego Ips duplicatus C. R. Sahlb. na południu Polski [Possibilities of population count control of Double-spined bark beetle Ips duplicatus]. Sylwan, 11, 25-36 [in Polish].

Grodzki, W. (2003). Zasięg występowania kornika zrosłozębnego Ips duplicatus C. R. Sahlb. (Col.,
Scolytidae) w obszarach górskich południowej Polski [Distribution range of the double spined bark beetle Ips duplicatus C. R. Shalb. (Col., Scolytidae) in the mountain areas of southern Poland]. Sylwan, 8, 29-36 [in Polish].

Grodzki, W. (2012). Two types of Norway spruce Picea abies (L.) H. Karst. infestation by the double spined bark beetle Ips duplicatus C. R. Sahlb. (Coleoptera: Scolytinae) in southern and north-eastern Poland. Folia For. Pol., Ser. A, Forestry, 54(3), 169-174.

Grodzki, W., Mokrzycki, T. (2014). Drzewotocz japoński - Xylosandrus germanus (Bldf.) i inne nowe gatunki korników w faunie Polski - występowanie i potencjalne zagrożenia dla drzewostanów [Xylosandrus germanus (Bldf.) and other new species of bark beetles in the Polish fauna - occurrence and potential risks to forest stands]. Biblioteczka Leśniczego 364. Warszawa: SITLD, Wyd. Świat [in Polish].

Hirschheydt, J. von (1992). Der amerikanische Nutzholzborkenkäfer Gnathotrichus materiarius (Fitch) hat die Schweiz erreicht. Mitteilungen der Schweizerischen. Entomol. Gesellsch., 65, 33-37.

Holuša, J., Lukášová, K., Trombik, J. (2013). The first record of Ips duplicatus (Coleoptera: Curculionidae, Scolytinae) infestations in Central European inner mountains. Sci. Agric. Bohem., 44(2), 97-101.

http://www.iop.krakow.pl/ias/gatunki [dostęp: 15.11.2015]. http://www.europe-aliens.org/speciesFactsheet.do?species $\mathrm{Id}=51474 \#$ [dostęp: 15.11.2015].

Jurc, M., Bojovic, S., Fernández, M. F., Jurc, D. (2012). The attraction of cerambycids and other xylophagous beetles, potential vectors of Bursaphelenchus xylophilus, to semio-chemicals in Slovenia. Phytoparasitica, 40(4), 337-349.

Kirkendall, R. L., Faccoli, M. (2010). Bark beetles and pinhole borers (Curculionidae, Scolytinae, Platypodinae) alien to Europe. ZooKeys, 56, 227-251.

Knížek, M. (2009). Faunistic records from the Czech Republic - 272. Coleoptera: Curculionidae: Scolytinae. Klapalekiana, 45, 22.

Knížek, M. (2011). Scolytinae. In I. Löbl, A. Smetana (Eds.), Catalogue of Palaearctic Coleoptera. Vol. 7. Curculionoidea I (pp. 204-251).

Knížek, M., Liška J. (2012). Kůrovcovitína smrku w podmínkách Česka. In Ochrona lasu - wybrane problem historyczne i współczesne (pp. 121-127). Poznań: Wyd. UP.

Knižek, M., Zahradník, P. (1996). Mass Outbreak of Ips duplicatus Sahlberg (Coleoptera, Scolytidae). In J. Doe (Ed.), XX International Congress of Entomology - Proceedings. August 25-31 1996. Firenze, Italy. 
Köhler, F. (2000). Erster Nachtrag zum „Verzeichnis der Käfer Deutschlands". Entomol. Nachrich. Berich., 44(1), 60-84.

Köhler, F., Klausitzer, B. (Eds.) (1998). Verzeichnis der Käfer Deutschlands. Entomologische Nachrichten und Berichte, Beiheft, 4, 1-185.

López S., Iturrondobeitia, J. C., Goldarazena, A. (2007). Primera cita en la Península Ibérica de Gnathotrichus materiarius (Fitch, 1858) y Xylosandrus germanus (Blandford, 1894) (Coleoptera: Scolytinae). Boletín Soc. Entomol. Aragon., 40, 527-532.

Mokrzycki, T. (2015). Nowe gatunki korników (Coleoptera, Curculionidae, Scolytinae) w faunie Polski i potencjalne zagrożenia dla drzewostanów [New species of bark beetles (Coleoptera, Curculionidae, Scolytinae) in the Polish fauna and potential risks to forest stands]. IX Sympozjum Ochrony Ekosystemów Leśnych, Rogów 23-24 września 2015 [in Polish].

Mokrzycki, T., Hilszczański, J., Borowski, J., Cieślak, R., Mazur, A., Miłkowski, M., Szołtys, H. (2011). Faunistic review of Polish Platypodinae and Scolytinae (Coleoptera: Curculionidae). Pol. Pism. Entomol., 80(2), 343-364.

Moucheron, B, Warzee, N. (2006). Gnathotrichus materiarius (Fitch, 1858): un scolyte nordamericain a surveiller, nouveau pour la faune Belge (Coleoptera, Scolytidae). Lambillionea, 106, 610-612.

Postner, M. (1974). Scolytidae Borkenkäfer. In W. Schwenke (Ed.), Die Forstschädlinge Europas. Bd 2. Käfer (pp. 334-482). Hamburg, Berlin: Paul Parey.

Schedl, K. E. (1966). Ein für Deutschland und Holland neuer Borkenkäfer. Anzeig. Schädling., 39, 118-120.
Schedl, K. E. (1980). Catalogus Faunae Austriae, XV: Coleoptera, Scolytidae und Platypodidae. Wien: Österreichische Akadaemie der Wissenschaften.

Schneider, I. (1985). Gnathotrichus materiarius Fitch (Col., Scolytidae) in Pheromonfallen von Ips cembrae (Heer) (Col., Scolytidae) ein neuer Fundort für NWDeutschland. Anz. Schädling. Phflanzen. Umweltsch., 58, 50-51.

Schroeder, L. M. (1990). Occurrence of insects in coniferous roundwood imported to Sweden from France and Chile. EPPO Bull., 20, 591-596.

Sweeney, J., de Groot, P., Humble, L., MacDonald, L., Price, M., Mokrzycki, T., Gutowski, J. M. (2007). Detection of wood-boring species in semiochemical-baited traps. In H. Evans, T. Oszako (Eds.), Alien invasive species and international trade (pp. 139-144). Warszawa: IBL.

Valkama, H., Martikainen, P., Räty M. (1998). First record of North American ambrosia beetle Gnathotrichus materiarius (Fitch) (Coleoptera, Scolytidae) in Finland a new potential forest pest? Entomol. Fenn., 8, 193-195.

Wood, S. L. (1982). The bark and ambrosia beetles of North and Central America (Coleoptera Scolytidae), a taxonomic monograph. Great Basin Nat. Memoir., 6, 1-1359.

Wood, S. L., Bright, D. E., (1992). A Catalog of Scolytidae and Platypodidae (Coleoptera). Part 2: Taxonomic index. Vol. B. Great Basin Nat. Memoir., 13, 1-1557.

Zach, P., Topp, W., Kuflan, J., Simon, M. (2001). Colonization of two alien ambrosia beetles (Coleoptera, Scolytidae) on debarked spruce logs. Biologia (Bratislava), 56(2), 175-181.

\title{
GNATHOTRICHUS MATERIARIUS (FITCH, 1858) (COLEOPTERA: CURCULIONIDAE, SCOLYTINAE) - NOWY GATUNEK KORNIKA W FAUNIE POLSKI
}

\begin{abstract}
ABSTRAKT
Gnathotrichus materiarius (Fitch, 1858) jest gatunkiem obcym w faunie Europy. W Polsce gatunek ten nie był dotychczas notowany, choć przypuszczano, że może występować. Praca prezentuje pierwsze stanowisko G. materiarius w Polsce. Pojedynczy okaz chrząszcza odłowiono podczas monitoringu kornika zrosłozębnego - Ips duplicatus (Sahlb.) w pułapki feromonowe z feromonem ID Ecolure w leśnictwie Krzeszów Nadleśnictwa Kamienna Góra. Przedyskutowano wybrane aspekty ekologii tego gatunku w warunkach europejskich: odławianie się chrząszczy w pułapki feromonowe na różne korniki drzew iglastych, małą liczebność gatunku, możliwość istnienia dwóch generacji w sezonie oraz pionowe rozmieszczenie na różnych wysokościach nad poziomem morza.
\end{abstract}

Stowa kluczowe: Gnathotrichus materiarius, nowy gatunek dla Polski, pułapki feromonowe 